\title{
Виктор Иванович Шестаков и логическое моделирование
}

В. И. ЛЕВин

ABSTRACT. The scientific biography of the outstanding cybernetician V.I. Shestakov, one of pioneers in logic modelling in technics is stated and analysed. The short analysis of his basic works is given. His mutual relations with other scientists, features of his person are considered. The full bibliography of his scientific publications is presented.

Ключевые слова: дискретные схемы, логическое моделирование, логическое проектирование, история приложений логики

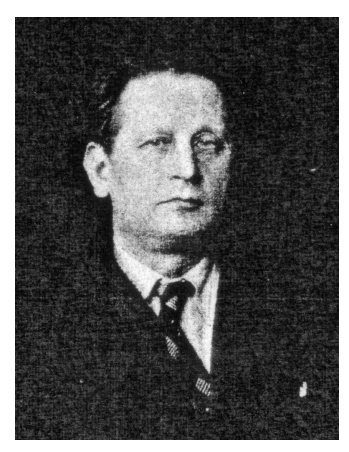

В.И. Шестаков.

\section{1 Введение}

В последние годы значительно возрос интерес к научной биографии советского ученого-кибернетика Виктора Ивановича Шестакова [1-8]. Это неудивительно, поскольку В.И. Шестаков был выдающимся ученым, одним из первооткрывателей логического моделирования технических устройств, который, по мнению многих российских историков науки, при жизни был недооценен 
как за рубежом, так и у себя на родине. Одной из причин интереса к ученому явилось также то, что в его трудах, наряду с традиционными задачами логического моделирования дискретных устройств, рассматривалась аналогичная задача для непрерывных (аналоговых) устройств. В имеющихся публикациях о В.И. Шестакове довольно подробно описаны основные этапы научного пути ученого, основные классы рассмотренных им задач логического моделирования технических устройств, его столкновения с другими учеными по вопросу приоритета на открытие логического моделирования в технике $[2,3,5-8]$. Однако многие важные вопросы остались не освещенными. Например, что из сделанного В.И. Шестаковым принадлежит только ему и отсутствует в работах других ученых; чем его работы отличаются методически; каким образом он - физик по образованию - пришел в область исследований «логика и техника»; почему идею логического моделирования релейных схем, родившуюся у него в 1935 году, он опубликовал лишь в 1941 году, поставив под вопрос свой приоритет открытия; почему он никогда не ссылался на работы других участников данного открытия; каковы были человеческие и общественно-политические взгляды ученого, что он представлял собой как человек, товарищ, семьянин; кто были его друзья и враги; при каких обстоятельствах С.А. Яновская провозгласила его в 1948 году первооткрывателем логического моделирования в технике; почему он остался недооцененным в мире и на родине.

В настоящей статье сделана попытка ответить на некоторые из указанных вопросов. Полученные в статье результаты позволяют по-новому взглянуть на историю открытия логического моделирования в технике.

\section{2 Начало пути}

Выдающийся российский ученый, пионер применения логики в технике и физике, автор первых работ в этой области в СССР и один из первых в мире, Виктор Иванович Шестаков родился 15 октября (по старому стилю) 1907 года в Москве. Его родителями были Иван Васильевич Шестаков (1880 г. рожд.) крестьянин Курской губернии и его законная жена Мария Бонифатьевна Погоржельская (рожд. в 1876 году, г. Двинск), оба 
«православного вероисповедания» (М.Б. была рождена в католичестве, полькой, дочерью Бонифатия Погоржельского, активного участника восстания за независимость Польши в 1863 году, сосланного затем в Россию). K моменту рождения Вити в семье уже был один сын - Владимир (1906 г.р.). Иван Васильевич почти до самой смерти в 1918 г. работал слесарем Главных железнодорожных мастерских Белорусско-Балтийской (Александровской) железной дороги. В конце своих дней И.В. работал начальником железнодорожного депо. Путем самообразования он познакомился с историей, естествознанием; изучал иностранные языки, т.е. был образованным для своего круга и времени человеком. Мария Бонифатьевна до 1918 г. была домашней хозяйкой, но после смерти мужа, оставшись вдовой с двумя детьми на руках, была вынуждена устроиться чернорабочей на вагоноремонтный завод «Памяти революции 1905 г.». В этот период дети оказались без присмотра, Виктор даже некоторое время беспризорничал на Сухаревском рынке в Москве. Вдобавок М.Б. заболела туберкулезом. В итоге младшего сына Витю и старшего Володю пришлось перевести из начальной школы железнодорожного поселка ст. Юдино Александровской железной дороги, где они учились с 1915 года, в интернат 1-й Трудовой опытнопоказательной школы Наркомпроса. Здесь Витя проучился до 1926 г., окончив 9 классов. Витя был слабым ребенком, часто болел, в основном, болезнями дыхательных путей (круппозный ларингит, многократные воспаления легких и т.д.), а после смерти матери от туберкулеза в 1920 г., оставшись в 13 лет круглым сиротой, болел практически непрерывно, заработал туберкулезный бронхоаденит и, начиная с 1923 г., до окончания школы находился под наблюдением врачей в туберкулезном диспансере. По оценке самого В.И. Шестакова, в школе он «проявил большую склонность и некоторые способности к технике, физике и математике». ${ }^{1}$ В школе он много занимался теоретически и экспериментально электричеством и радио, что дало знания физики, превышающие программу средней школы, но самое важное, по мнению самого В.И., это «привычку мыслить физически и работать самостоятельно по физике и применять в этой области математику». ${ }^{1}$ Хвалебный отзыв об успеваемости Вити - «третьего ученика в классе» ${ }^{1}$ - дала также школа, где 
он учился. Его школьные знания по физике и математике, повидимому, были действительно хороши - впоследствии он никогда не проваливался на экзаменах по этим дисциплинам, а, наоборот, показывал результаты лучшие, чем большинство других экзаменующихся. ${ }^{1}$

В 1926 г. В.И. Шестаков предпринял первую, увы, неудачную, попытку поступить в ВУЗ - на электротехнический факультет МВТУ. Он выдержал конкурс по письменной математике (который не прошли 125 человек), но «провалил» политэкономию. После этой неудачи он пошел работать - сначала служащим Института методов внешкольной работы (1926-27 гг.), потом чернорабочим механического завода (1927-28 гг.). С марта 1928 г. он оказался безработным и жил на пособие по безработице, а в период 1928-29 гг., как член профсоюза, перебивался временной работой по направлениям Биржи труда. В 1928 г. В.И. Шестаков совершил новую, к сожалению, опять неудачную попытку поступить в ВУЗ, на этот раз - на физический факультет 1-го МГУ: он не прошел по конкурсу. Однако уже через несколько месяцев ему повезло: весной 1929 г. (в середине учебного года, в рамках актуальной тогда «задачи химизации страны») его принимают на химический факультет МВТУ. Виктор был счастлив. Но вскоре ситуация, а вместе с ней и его настроение изменились. Выяснилось, что когда на занятиях требовалось знание материала по химии, он «плавал»; там же, где требовались сообразительность, логика рассуждений, умение строить структуры (те же химические), там он «чувствовал себя лучше». ${ }^{1}$ Он с удовольствием занимался на 1-м курсе аналитической геометрией (по Соколовскому), теоретической механикой (по Бухгольцу), а на 2-м курсе «прошел электричество на первом месте в группе» ${ }^{1}$ и даже «спорил с преподавателем, хотя группа стояла на другой точке зрения, занимался с отстающими по физике». ${ }^{1}$ В конце 2 курса В.И. Шестакову дважды предлагали аспирантуру - по химии и по диалектическому материализму, но он отказался от обоих предложений, т.к. это «не отвечало его физикоматематическим наклонностям». ${ }^{1}$ В 1929 году, будучи студентом 2-го курса химфака МВТУ, он впервые совершил «пробу пера» ${ }^{1}$ в виде студенческих научных работ по математике и физике. Сам Виктор Иванович так оценивал эти свои труды: «Это 
не научные открытия, не открытие «Америки», а просто самостоятельные работы, на которые я с удовольствием трачу свое время и энергию». ${ }^{1}$ Эти его занятия завершились ходатайством о переводе его на физический факультет 1-го МГУ: «Дайте мне возможность заниматься этим делом не урывками, а как основной работой». ${ }^{1}$ В связи с этим В.И. Шестаков замечает: «Ничего подобного не замечается в химии: за 1,5 года у меня ни одной мысли не мелькнуло по химии». ${ }^{1}$

«Крик души» начинающего ученого был услышан, и осенью 1930 года его перевели с 3-го курса Высшего Химико-Технологического Училища (бывший химфак МВТУ) на 2-й курс физического факультета 1-го МГУ им. М.Н. Покровского (т.е. с потерей курса). Однако предшествующее двухлетнее пребывание на химфаке МВТУ и связанная с этим работа в химических лабораториях и на химических предприятиях не прошли даром: его здоровье, начавшее улучшаться после окончания в 1926 г. школы-интерната, снова ухудшилось. Все завершилось месячной практикой Виктора Ивановича в мае 1930 года на Макеевском коксобензольном заводе. Из-за постоянного плохого самочувствия и повышенной температуры он уехал из Макеевки домой, не дождавшись конца практики, за что у него была «отнята хлебная карточка». ${ }^{1}$ В родной Москве его опять взяли под наблюдение в туберкулезном диспансере как больного туберкулезным бронхоаденитом.

Переход в МГУ придал В.И. Шестакову новые творческие силы. Уже через полтора года, 08.02.1932 г., будучи студентом четвертого курса, он подал в Комитет по изобретательству заявку на изобретение счетной машины нового типа и 31.03.1934 г. получил Свидетельство на изобретение. ${ }^{2}$ В июне 1934 г. он защитил на «отлично» диплом по теме «Теоретическое исследование спектра гармонического осциллятора при наличии случайных скачков фазы (задача Лоренца)», которой он успешно занимался на старших курсах под руководством известного физика, специалиста по теории колебаний проф. С.Э. Хайкина. В дипломе, выданном Шестакову, была указана его квалификация - «научный работник 2-го разряда в области «Колебания», преподаватель ВУЗа и ВТУЗа, а также техникумов, рабфаков и старших классов средней школы». ${ }^{3}$ Осенью того же 1934 г. В.И. Шеста- 
ков поступил в аспирантуру НИИ физики МГУ (лаборатория теории колебаний). Его поселили, выделив койку в общежитии МГУ. Началась новая жизнь - жизнь ученого.

В качестве научного руководителя Виктору Ивановичу выделили квалифицированного специалиста по физической теории колебаний проф. Горелика. Однако нормальные отношения между аспирантом и руководителем не сложились. Все темы диссертаций, которые аспиранту могли предложить в лаборатории, были, естественно, связаны с теорией колебаний. Однако теперь эта тематика его не устраивала. ${ }^{4}$ Шестаков все же выбрал одну из предложенных ему тем, но реальной работы по ней так и не начал. Его интересы перешли в совсем другую область, связанную с применением алгебры логики к теории сложных схем из реле. Его отношения с научным руководителем обострились. В декабре 1934 г. руководитель в своем отзыве жаловался, что его подопечный «в течение 3 месяцев не начинал работу...», а в феврале 1935 г. он прямо указал, что «выполнение плана аспирантской работы тов. Шестаковым должно быть признано неудовлетворительным. Исследования Шестакова в области применения алгебры логики к схемам реле... не гарантирует защиту им кандидатской диссертации». Тем не менее, определенный результат изыскания Шестакова дали: в январе 1935 г. он подготовил работу «Реле и релейные схемы» с основным разделом «Алгебра релейных схем», которая, хотя она и носила предварительный характер и не предназначалась для публикования, сыграла роль трамплина в его последующих, более обстоятельных работах. ${ }^{5}$ Интенсивная работа привела снова к обострению туберкулеза и в феврале 1935 г. Виктор Иванович ушел в академический отпуск до осени. Во время отпуска В.И. Шестаков лечился в санатории (Башкирия). Там он познакомился с Геней Абрамовной Гурфинкель (1913 г.р.). Вскоре В.И. Шестаков женился на Г.А. и переехал в ее 18-метровую комнату. Там же жила и мать молодой жены - Эмилия Соломоновна Гурфинкель (1890 г.р.). Условия жизни молодоженов были ужасны (см. книгу [8], гл. 13). Тем не менее, женитьба пошла на пользу Виктору Ивановичу: уже к осени 1935 года он снова полон творческих сил и продолжает начатые исследования - уже под руководством нового, более соответствую- 
щего его теме научного руководителя, выдающегося специалиста по алгебре, логике и теории вероятностей д-ра физ.-мат. наук профессора Валерия Ивановича Гливенко. Именно В.И. Гливенко первым обратил внимание В.И. Шестакова на рецензию П. Эренфеста по книге Л. Кутюра «Алгебра логики», в которой впервые была высказана мысль о возможном использовании алгебры логики для описания и конструирования релейноконтактных схем, и поддержал молодого ученого профессионально и морально. Следующий, 1936-й год оказался для Виктора Ивановича успешным и в научной, и в семейной жизни: у него родилась дочь Ирина, а он, пользуясь советами и помощью В.И. Гливенко, разработал логико-математический аппарат для описания релейно-контактных и обычных (непрерывных) электрических схем, причем первые рассматривались как предельный, вырожденный случай вторых. Это дало возможность уже весной 1937 года приступить к написанию диссертации. Срок пребывания в аспирантуре был продлен на 4 месяца, что позволило точно в срок - 9 января 1938 года закончить диссертацию. Она называлась «Некоторые математические методы конструирования и упрощения двухполюсных электрических схем класса А». В ней В.И. Шестаков первый в СССР и один из первых в мире применил к расчету двухполюсных электрических схем с последовательными и параллельными соединениями элементов аппарат алгебры логики. ${ }^{6}$ Начались поиски оппонентов: сначала отказался профессор С.А. Лебедев, потом согласившийся оппонировать сотрудник его лаборатории Д.И. Марьяновский оказался не доктором наук. Подходящей фигурой был член-корреспондент АН СССР, редактор журнала «Автоматика и телемеханика» В.И. Коваленков, согласившийся быть оппонентом и опубликовать материал диссертации в своем журнале. Однако, взяв диссертацию в марте 1938 г. на просмотр, он вернул ее через 1,5 месяца, отказавшись от всех своих обещаний. В конце концов, 1-м оппонентом стал доктор технических наук Лаврентьев из Наркомтяжпрома и математик - профессор И.И. Жегалкин из МГУ. Защита диссертации состоялась 28 сентября 1938 г. и прошла успешно. В диссертации соискатель установил соответствие между соединениями электрических сопротивлений (в частности, реле) и логическими операциями и 
выяснил физические основания такого соответствия. В январе 1939 г. ВАК присудил В.И. Шестакову ученую степень кандидата физико-математических наук. Заметим, что диссертацию В.И. Шестаков защитил, не имея ни одной публикации! Такие защиты в то время были обычным явлением: люди больше работали, чем публиковались. После окончания аспирантуры в январе 1938 г. В.И. Шестаков все годы работал преподавателем кафедры общей физики физического факультета МГУ - сначала ассистентом, а с конца 1941 г. - доцентом. Интересно, что окончив Физфак МГУ и проработав 50 лет преподавателем физики, В.И. так и не стал физиком. Сферой его интереса всегда была математическая логика и ее технические приложения (см. [8], гл. 13).

\section{3 Первые отзывы и первые столкновения}

1940-41 годы принесли В.И. Шестакову несколько сюрпризов. В июне 1940 г. в Физико-математическом реферативном журнале (T. IV. 1940. Вып. 2) появился первый опубликованный в печати отклик на его диссертацию: он содержался в реферате Д.И. Марьяновского статьи инж. В.А. Розенберга «Задача о блокировке и преобразование контактных групп», опубликованной в журнале «Автоматика и телемеханика», 1940, № 1. Это было приятно, но не удивительно, поскольку этот реферат был «заказан» Марьяновскому самим В.И. (они состояли в дружеских отношениях). А неприятное было в том, что перед этим, в апреле 1940 года, после ознакомления со статьей Розенберга Виктору Ивановичу показалось, что по содержанию она совпадает с его диссертацией, что и породило его «заказ». Он вспомнил, что в марте-апреле 1938 г. его диссертация находилась на просмотре у ответственного редактора этого журнала, который вернул ее автору, отказав и в оппонировании, и в публикации, и мысленно связал с этим событием факт появления публикации Розенберга. Реакция возмущенного несправедливостью (как ему казалось) В.И. Шестакова была быстрой. Незадолго до описываемых событий он подготовил большую статью с изложением основных теоретических положений его диссертации по применению математической логики к моделированию релейно-контактных последовательно-параллельных схем и 25.02.1940 г. с названием 
«Алгебра двухполюсных схем, построенных исключительно из двухполюсников (алгебра А-схем)» представил в «Журнал технической физики». Затем, подробно познакомившись со статьей Розенберга, он подготовил письмо о показавшихся ему совпадениях содержания этой статьи с его диссертацией и вместе с копией своей статьи «Алгебра двухполюсных схем. . .» 27 апреля 1940 г. отправил в редакцию журнала «Автоматика и телемеханика». Тогда же, вместе с письмом В.И. Шестакова, письмо аналогичного содержания в защиту своего сотрудника направили в редакцию этого журнала директор НИИ физики МГУ член-корр. АН СССР проф. А.С. Предводителев и профессор К.Ф. Теодорчик. 5 мая руководство НИИФ получило ответ из редакции о возможности опубликования их письма (при условии необходимой коррекции текста) совместно с объяснениями В.А. Розенберга. 17 мая редакция получила письмо от Розенберга. В этом письме главный инженер Ленпроектконторы «Сев. зап. эл. монтаж» В.А. Розенберг объяснил, что содержание работ В.И. Шестакова ему не известно, что алгебры Буля он не знает, а изобрел ее сам, а отмеченные Шестаковым совпадения считает нормальным явлением для специалистов, занимающихся одной предметной областью. ${ }^{7} 23$ мая в редакцию пришло повторное письмо от директора НИИФ Предводителева с предложенной журналом коррекцией текста. Однако после этого редакция передумала выносить переписку по столь щекотливому вопросу на страницы журнала. В ответ на запрос Шестакова от 11.10.1940 г. о судьбе дела редакция «Автоматики и телемеханики» 25.10.1940 г. письменно отказала ему и директору НИИФ в опубликовании их писем о приоритете работ Шестакова по логическому моделированию электрических схем, обосновав свою позицию тем, что вопрос приоритета является в данном случае спорным и потому должен решаться в судебном порядке. Вместе с тем, редакция предложила Виктору Ивановичу опубликовать присланную им в апреле статью «Алгебра двухполюсных схем...» в переработанном виде. Уже 20.11.1940 г. доработанная статья была получена редакцией. Доработка состояла в сокращении текста, исключении доказательств и доведении объема статьи до принятых в журнале норм. ${ }^{8}$ Одновременно, озабоченный вопросами своего приоритета и получив вдобавок на 
доработку свою статью из ЖТФ (август 1940 г.), В.И. Шестаков подготовил (видимо, для подстраховки) еще один - третий, весьма краткий (4-страничный) вариант своей статьи и под названием «Об одном символическом исчислении, применимом к теории электрических схем» 02.09.1940 г. представил в сборник «Ученые записки Московского университета». В итоге первая, основная и наибольшая по объему статья «Алгебра двухполюсных схем, построенных исключительно из двухполюсников (алгебра А-схем)» вышла в свет в марте 1941 г. (ЖТФ. Т. 11. 1941. Вып. 6), ее сокращенный вариант с тем же названием - в апреле 1941 г. («Автоматика и телемеханика», 1941. № 2). Публикация же последней, самой краткой версии статьи задержалась из-за войны на целых 4 года (Ученые записки Московского университета. Теория вероятностей. Вычислит. математика. Номография. 1944. Вып. 73.). Отметим еще, что в это же время (06.12.1940 г.) с просьбой о защите его приоритета в области применения алгебры Буля к электрическим схемам В.И. Шестаков обращался и в Президиум АН СССР. Однако ответа он, видимо, не получил. Обратиться же по этому вопросу в суд, как советовал журнал «Автоматика и телемеханика», он не решился. В итоге формально права на приоритет в данной области у Шестакова и В.А. Розенберга остались равными. ${ }^{9}$

1940-й год, по-видимому, сильно изменил жизненные установки и характер поведения Виктора Ивановича. Он понял, что не является единственным, кто разрабатывает тематику «Применение логических методов в технике»; этим занимаются многие - советский ученый В.А. Розенберг, немка Х. Пиш, австриец О. Плехль, японцы А. Накашима и М. Ханзава (об этом В.И. должен был узнать в феврале-августе 1940 г. ${ }^{10}$ ), американец К.Э. Шеннон (об этом В.И. должен был узнать в сентябре 1940 - апреле 1941 г. $^{11}$ ) и др. Вдобавок 15 марта 1940 г. умер его научный руководитель В.И. Гливенко и Виктор Иванович остался без научной поддержки. В этой новой для него ситуации он, очевидно, решил, что может надеяться только на себя и потому должен активизировать научную работу и опубликование ее результатов, с тем чтобы опередить своих конкурентов. В частности, он перестал заниматься линейными электрическими цепями, сосредоточив все усилия на тематике, занимавшей 
большинство других ученых: логические методы исследования релейно-контактных и других дискретных схем.

Начало Великой Отечественной войны внесло существенные коррективы в жизнь В.И. Шестакова. Будучи по состоянию здоровья не пригодным к прохождению службы в рядах Советской армии, он не подлежал призыву и направлению на фронт. Это сохранило ему жизнь, а России - выдающегося ученого. 13.10.1941 г. он получил «Удостоверение об эвакуации из Москвы с семьей из трех человек в г. Ашхабад», где по постановлению Правительства СССР уже находился МГУ. В эвакуации Шестаков находился до конца 1943 г. (сначала в Ашхабаде, затем Свердловске, куда перевели МГУ).

После возвращения из эвакуации в Москву В.И. Шестаков с еще большей интенсивностью включился в научную работу. При этом тематика его исследований заметно изменилась. Прежде всего он, как уже говорилось, перестал заниматься логическим моделированием обычных электрических схем и сосредоточил все усилия на изучении релейно-контактных схем. Во-вторых, он понял, что применение аппарата алгебры логики полезно при изучении не только управляющих систем (таких как релейноконтактные схемы), но и вычислительных машин дискретного действия (причем логики не только двузначной, но и многозначной). ${ }^{12}$ В связи с этим в период с 1949 по 1953 г. он работал по совместительству сначала младшим, а с 1950 г. - старшим научным сотрудником в Институте точной механики и вычислительной техники АН СССР (специальность «вычислительная техника»). Там он разрабатывал новую в то время область программирование и решение математических задач на цифровых ЭВМ. К этому времени относятся также его перевод с английского языка главы XIII «Арифметические элементы» в книге «Быстродействующие вычислительные машины» (перевод с англ. под ред. Д.Ю. Панова. М. 1952 г.), написание совместно с А.А. Абрамовым и М.Р. Шура-Бура, под ред. чл.-корр. АН СССР Л.А. Люстерника первой отечественной монографии по программированию «Решение математических задач на автоматических цифровых машинах. Программирование для электронных счетных машин» (М. 1952), перевод с английского языка, а также редактирование книги «Синтез электронных вычисли- 
тельных и управляющих схем» (M. 1954). За названную выше коллективную монографию В.И. Шестаков и три его соавтора в 1952 г. получили премию Президиума АН СССР. Это было не первое признание научных заслуг В.И. Шестакова. А первое признание произошло в 1948 г.: в статье известного логика С.А. Яновской «Основания математики и математическая логика» (Математика в СССР за 30 лет (1917-1947). Т. 2. Гостехтеориздат. М.-Л.) было сказано, что в работе «Алгебра релейных схем», написанной Шестаковым в январе 1935 года, ${ }^{5}$ впервые в мире была подтверждена возможность построения алгебры релейно-контактных схем на базе алгебры логики. Еще два признания были получены в 1949 году. В отзыве о работах Виктора Ивановича от 15.10.1949 г. будущего академика П.С. Новикова было сказано, что его работа «Алгебра релейных схем», сделанная в январе 1935 года, содержала принципы нового расчета релейных схем. А в дальнейшем особая роль в науке Виктора Ивановича проявилась в том, что он первый ввел в технику метод расчета путем установления аналогии между областями, казалось бы, совершенно далекими и тем самым явился основоположником нового направления в технических науках. В отзыве о работах Виктора Ивановича Шестакова от 22.10.1949 г. профессора М.А. Гаврилова отмечен пионерский характер его работ по применению математического аппарата теоретической логики к решению задач синтеза и анализа релейно-контактных схем. ${ }^{13}$ Заметим, что помимо научной работы, много времени Виктор Иванович всегда уделял реферированию работ других авторов. Только в период с 1938 по 1955 гг. он прореферировал 54 работы, включая два перевода с языка оригинала.

После возвращения в Москву из эвакуации семья В.И. Шестакова получила 19-метровую комнату в Пушкинском студенческом городке в Останкино - в деревянном стандартном доме, построенном по коридорной системе. С молодыми теперь не было тещи - она осталась в своей довоенной комнате. К сожалению, не было не только тещи, но также водопровода, канализации, центрального отопления. И находилась эта комната в 1,5 часах езды от работы. В 1954 г. Виктору Ивановичу наконец повезло: по ходатайству ректора МГУ ему выделили 21,8-метровую комнату в коммунальной квартире на 4 семьи по 
Ломоносовскому проспекту. Этот «подарок» явился результатом заявления В.И. Шестакова ректору, где он просил об «исправлении вопиющей несправедливости ко мне, допущенной деканом физического факультета, уже вторично не включившим меня в список на получение квартиры в 14-этажном доме МГУ, в то время как деканат находит возможность включать в список на получение квартир во вторую очередь сотрудников, которым уже ранее были предоставлены благоустроенные квартиры».

В мае 1952 г. по приказу министра высшего образования СССР В.И. Шестаков был командирован в докторантуру МГУ сроком с 05.05.1952 г. по 05.11.1953 г. для выполнения докторской диссертации «Алгебраические методы анализа и синтеза систем с конечным числом устойчивых состояний» (научный консультант д-р физ.-мат. наук профессор К.Ф. Теодорчик). Согласно приказу В.И. Шестаков должен был представить краткий отчет о состоянии работы над диссертацией к 10.01.1953 г. и окончательный отчет о результатах выполнения диссертации и ее защите - по окончании срока пребывания в докторантуре. Цель диссертации формулировалась так: исследование и разработка алгебраических методов анализа и синтеза релейных систем дискретного действия, реле которых работают в некоторой последовательности, определяемой либо последовательностью внешних воздействий, либо структурой системы и начальными условиями в ней. Таким образом, речь шла о создании вычислительных методов изучения объектов, получивших впоследствии название «конечные автоматы». Напомним, что в описываемое время понятия «конечный автомат» еще не было. План диссертации включал введение, части 1 и 2 и заключение. Пять глав части 1 посвящалось системам из элементов с двумя устойчивыми состояниями, а три главы части 2 - системам с любым конечным числом состояний. Отчет Шестакова за 11 первых месяцев работы на имя ректора МГУ гласил: написана работа объемом 200 машинописных страниц, являющаяся теоретической частью диссертации; не осуществлена вторая часть, посвященная вопросам практического применения полученных результатов в области вычислительных машин, из-за неясности вопроса о секретности этой части диссертации. В окончательном отчете ректору МГУ о причинах невыполнения плана пребывания 
в докторантуре В.И. Шестаков объяснил все бытовыми проблемами с жильем и отсутствием поддержки МГУ с публикацией результатов. ${ }^{14}$

\section{4 Признание}

С 1953 г. В.И. Шестаков приступил к представлению на различных семинарах, а также к интенсивной подготовке и написанию статей по результатам, полученным в период пребывания в докторантуре и относящимся уже к тематике многотактных релейно-контактных схем, являющихся частным случаем конечных автоматов (в отличие от однотактных схем, изучавшихся В.И. в предшествующие годы). В течение короткого времени (6-7 лет) он опубликовал около 20 статей и докладов в самых известных изданиях страны (Доклады АН СССР, Автоматика и телемеханика, Логические исследования, Труды III Всесоюзного математического съезда и др.). Рецензии на эти работы писали самые авторитетные советские ученые: П.С. Новиков, С.А. Яновская, М.А. Гаврилов, С.Л. Соболев, М.А. Леонтович, В.С. Кулебакин и др. Основополагающими из этих статей являются «О преобразовании моноциклической последовательности в возвратную» (Доклады АН СССР. Т. 98. 1954. № 4), «Алгебраический метод синтеза многотактных релейных систем» (Доклады АН СССР. Т. 99. 1954. № 6) и «Алгебраический метод синтеза многотактных систем $r$-позиционных реле» (Доклады АН СССР. Т. 112. 1957. № 1). Эти работы Шестакова, выполненные независимо от проводившихся в тот же период исследований американских (А. Бёркс, Дж. фон Нейман, Д. Райт, Г. Эйкен, Д. Хаффмен, С. Клини, Ф. Муррей), румынских (Г. Моисил) и советских (В.Н. Рогинский, Б.А. Трахтенброт, Н.Е. Кобринский, В.М. Глушков) ученых совместно составили основу современной теории конечных автоматов - важной части современной дискретной математики. Именно в этот период произошло похолодание во взаимоотношениях В.И. Шестакова с М.А. Гавриловым, которые восходили еще к 1938 г., когда присутствовавший на докладе Виктора Ивановича Гаврилов первый оценил его работы и предсказал им большое будущее. Теперь же Шестаков заподозрил, что Гаврилов, будучи членом редколлегии журнала «Автоматика и телемеханика», придерживает его ста- 
тьи, пропуская вперед свои (статьи В.И. Шестакова «Алгебраический метод анализа автономных систем двухпозиционных реле» и «Алгебраический метод синтеза автономных систем двухпозиционных реле», написанные по просьбе редакции журнала 10.01.1953 г., с апреля по октябрь 1953 г. находились у Гаврилова, который в начале октября вернул их без отзыва, а 9 октября 1953 г. представил в журнал собственную статью «Основные формулы синтеза релейных схем». Опубликование же статей Шестакова отложили до 1954 года, одновременно обратившись к нему с просьбой дать отзыв на вышеуказанную статью Гаврилова). Шестаков тут же письменно потребовал от редактора журнала опубликования главной его статьи, посвященной синтезу релейных схем. $\mathrm{K}$ счастью, отношения между двумя учеными существенно не пострадали, обе статьи Шестакова были вскоре опубликованы в журнале (1954. № 2 и 1954. № 4), и Виктор Иванович в последующие годы достаточно долго, как и прежде, участвовал в семинарах Гаврилова и публиковался в журнале «Автоматика и телемеханика». ${ }^{15}$ Аналогичная задержка публикации случилась со статьей В.И. Шестакова «Алгебраический метод синтеза автономных релейных систем», представленной в 1954 г. акад. П.С. Новиковым в журнал «Доклады АН СССР». Дважды (14.05. и 09.06.1954) академик обращался к главному редактору журнала в поддержку статьи. Тем не менее, она так и не была опубликована - задержка оказалась столь велика, что появился новый, более общий вариант статьи, содержащий общее решение задачи синтеза как автономных, так и неавтономных релейных систем.

Примерно в то же время произошло столкновение В.И. Шестакова с А.Н. Колмогоровым - вероятно, наиболее близким ему по характеру дарования и кругу тогдашних интересов ученым. Еще в 1946 году Колмогоров поддержал большую работу Шестакова «Представление характеристических функций предложений посредством выражений, реализуемых релейно-контактными схемами», представив ее в журнал, где статья вскоре была опубликована (Известия АН СССР. Серия математическая. 1946. Т. 10. № 6). Однако теперь, в 1953 г., во время выступления Шестакова на семинаре по логике в МГУ с изложением своих результатов по анализу и синтезу многотактных 
релейно-контактных схем, Колмогоров оценил эти результаты как изучение весьма частного случая цепей Маркова и раскритиковал их, как не содержащие новизны. После этого пути двух ученых разошлись. ${ }^{16}$

Надо заметить, что В.И. Шестаков схватывался не только с советскими учеными, которые, по его мнению, были его конкурентами и/или мешали опубликованию его работ (В.А. Розенберг, М.А. Гаврилов, А.Н. Колмогоров), но и с соответствующими зарубежными учеными. Так (по свидетельству Э. Кольмана) в апреле 1957 г. он публично «весьма резко опровергал кибернетику, как «лженауку»... Шестаков не знал, что он сам и есть кибернетик». По нашему мнению, ученый поступал так не по незнанию, а потому, что для него в кибернетике после работ его конкурента К. Шеннона не осталось места. Такая кибернетика была ему не нужна. ${ }^{17}$

В эти годы последовало еще несколько признаний достижений В.И. Шестакова. 28 октября 1953 года по поводу работы В.И. «Анализ и синтез релейных систем, построенных из элементов, имеющих только два устойчивых состояния» д.ф.-м.н. проф. С.А. Яновская написала: «Представляется имеющей важной значение гл. III, посвященная автономным и неавтономным системам. Проблема анализа и синтеза таких систем, последующие состояния которых определяются их предшествующими состояниями, представляет особый интерес с точки зрения технических приложений для математических вычислений...». В 1954 г. в статье «Логика математическая» (БСЭ, 2 изд., Т. 25. 1954) чл.-корр. АН СССР А.А. Марков указал: «Советским ученым в 30-х гг. было открыто важное применение классического исчисления высказываний к релейно-контактным схемам, широко используемое в автоматических устройствах. Рассматривая двухполюсную релейно-контактную схему, Шестаков заметил, что всякая такая схема... моделирует некоторую формулу классического исчисления высказываний». В 1959 году в статье «Логика и автоматизация» («Логические исследования». Сб. статей. М. Изд-во АН СССР. 1959) известный ученый-кибернетик Г.Н. Поваров отметил: «Строгое доказательство того, что булева алгебра описывает логически структуру релейно-контактных схем, и первые систематические методы синтеза, основанные на 
применении булевой алгебры, были даны в 30-х годах В.И. Шестаковым и К.Э. Шенноном. Кроме того, А. Накасима и М. Хандзава, В.А. Розенберг и Иоганна Пиш построили специальные схемные алгебры, фактически совпадающие с булевой алгеброй, но не отметили сразу этого совпадения». ${ }^{18}$ При этом Поваров ссылается на кандидатскую диссертацию Шестакова 1938 г. и его статью в Журнале технической физики 1941 года (см. библиографию работ В.И. Шестакова), статью К.Э. Шеннона 1938 года ${ }^{11}$, две статьи И. Пиш 1939 года ${ }^{10}$, две статьи А. Накашимы 1936 и 1938 гг. на английском языке и статью В.А. Розенберга 1940 г. (см. выше). В том же 1959 г. чл.-корр. АН СССР А.А. Ляпунов в статье «Математические исследования, связанные с эксплуатацией ЭВМ» («Математика в СССР за 40 лет». М. Физматгиз. 1959. Т. 1) написал: «В.И. Шестаков предложил векторноалгебраический метод синтеза автономных релейно-контактных схем, который был им обобщен и на неавтономные схемы», а С.А. Яновская в статье «Математическая логика и основания математики» (там же) отметила: «В теории конечных автоматов В.И. Шестаков разрабатывал методы получения по уравнениям, схеме какого-либо автомата отвечающего им процесса (анализ системы) и обратно: уравнений по характеру процесса (синтез системы)».

В 1950-е - 1960-е годы сфера деятельности В.И. Шестакова заметно расширилась. Наряду с реферированием научных работ для различных реферативных журналов, чем он занимался и раньше (являясь внештатным редактором раздела «Алгебра (математическая теория) электрических цепей» реферативного журнала «Математика»), он стал вести ряд научных семинаров. Так, в 1953-54 годах он стал одним из руководителей семинара «Алгебра логики и релейно-контактных схем» на механикоматематическом факультете МГУ. Он также руководил другим постоянным семинаром по техническим приложениям математической логики, созданным в октябре 1955 г. в МГУ по инициативе С.А. Яновской. На семинарах обсуждались главным образом проблемы анализа и синтеза (в том числе структурного) контактных и бесконтактных релейных схем. В 1950-х 60-х годах он стал также руководителем прекрасного (по отзывам участников) семинара по теории релейных схем в уни- 
верситете - сначала при кафедре истории математики, затем при кафедре общей физики, который собирал много участников из разных учреждений Москвы и превратился в своеобразный клуб, который сыграл важную роль в развитии и пропаганде новых методов изучения релейно-контактных схем. Тематика этого семинара была аналогична тематике семинара по техническим приложениям логики. Кроме сказанного, В.И. Шестаков занимался также популяризацией применений логики в технике. Так, в журнале «Математика в школе» $(1958$, № 6; 1959, № 1) он опубликовал большую научно-популярную статью «Математическая логика и автоматика», написанную по результатам его исследований.

В конце 1950-х - 1960-е годы В.И. Шестаков много внимания уделил разработке вопросов многозначной (в основном, трехзначной) логики и ее использования для математического моделирования, анализа и синтеза релейно-контактных схем на многопозиционных реле. Он опубликовал довольно значительное число статей по этой тематике («Алгебраический метод синтеза многотактных систем $r$-позиционных реле». Доклады АН СССР. Т. 112. 1957. № 1; «Моделирование операций исчисления высказываний посредством релейно-контактных схем». Логические исследования. Выпуск 2. М. Изд-во АН СССР. 1959; «О двойной арифметической интерпретации трехзначного исчисления высказываний, используемой при моделировании этого исчисления посредством релейно-коммутаторных схем». Применение логики в науке и технике. М. Изд-во АН СССР. 1960; «О взаимоотношении некоторых трехзначных логических исчислений». Успехи математических наук. 1964. Т. 19. Вып. 2 и др.). Все они явились дальнейшим развитием его вышеупомянутой статьи «Представление характеристических функций предложений...» 1946 года, в которой, видимо, впервые была показана возможность технических приложений многозначных логик. В этот же период Шестаков опубликовал ряд статей по использованию аппарата алгебры логики для построения конкретных вычислительных и управляющих (логических) устройств («Синтез параллельного сумматора двоичных чисел, построенного из двухполюсных переключателей и поляризованных реле». Вопросы теории математических машин. Т. 2. 1962; «Логические машины». Философ- 
ская энциклопедия. Т. 3. М. Советская Энциклопедия. 1964. с Б.В. Бирюковым и Л.А. Калужниным и др.).

В 1960-е годы продолжился процесс признания научных заслуг В.И. Шестакова. В 1964 году в статье «Релейно-контактных схем теория» (Автоматизация производства и промышленная электроника. М. Сов. Энциклопедия. Т. 3. 1964) О.П. Кузнецов отметил: «Релейно-контактных схем теория возникла в 1936-38 годы после работ В.И. Шестакова, К. Шеннона, А. Накасимы и М. Ханзавы» и еще: «Началом развития... теории являются 1936-38 гг., когда В.И. Шестаков, К. Шеннон и А. Накашима применили для решения задач... теории аппарат математической логики». В 1968 году в письме декана физфака МГУ А.С. Предводителева в редакцию «Вестника Московского университета. Сер. 3» (1968. № 5) «K истории применения алгебры Буля в технике» была отмечена роль В.И. Шестакова в применении символической логики к анализу и синтезу релейных схем и указано наличие документов, подтверждающих приоритет Виктора Ивановича в этой области. В частности, приведен отзыв профессора В.И. Гливенко от 06.01.1936 г. о работе В.И. Шестакова по подготовке кандидатской диссертации. ${ }^{19}$

В эти же годы В.И. Шестаков в очередной раз попытался улучшить свои жилищные условия. В своем заявлении начальству (1958 г.) он писал: «На факультете почти за 20 лет работы в университете у меня нет даже отдельного письменного стола, хотя я веду научную работу творческого характера в новом, начатом мною впервые в СССР, направлении. В домашних условиях работать мне также очень трудно: кроме моей семьи в квартире, где я проживаю, еще три больших семьи, все с маленькими детьми - на 4 комнаты прописанных жильцов 17 человек, не считая временно проживающих. В одной с нами комнате взрослая дочь-студентка». В итоге в 1962 г. Виктор Иванович получил отдельную комнату в 19 кв.м. на Ломоносовском проспекте, рядом с МГУ. И лишь в 1963 г. в 56 лет всемирно известный ученый впервые в жизни приобрел отдельную двухкомнатную квартиру общей площадью 43 кв.м (жилой площадью 31,6 кв.м) по ул. Лобачевского (путем обмена его однокомнатной квартиры и комнаты в коммуналке тещи). 


\section{5 Итоги}

Помимо научной и преподавательской работы, В.И. Шестаков в 1960-е гг. много времени уделял редактированию и рецензированию иностранной научной литературы. Так, в 1963 году он редактировал переводимую В.М. Остиану с румынского книгу Гр. Моисила «Алгебраическая теория дискретных автоматических устройств» и рецензировал книгу Whitesitt J.Е. «Булева алгебра и ее приложения», а в 1964 г. рецензировал книги Гудстейна Р.Л. «Булева алгебра» и Флегга Х.Г. «Булева алгебра и ее приложения». Он также принял деятельное участие в подготовке и реализации Директивы Совета по Кибернетике при Президиуме АН СССР от 22.05.1965 г. о проведении мероприятий по развитию исследований в области теории релейных устройств и конечных автоматов, по внедрению этой теории и развитию ее преподавания во ВТУЗах. В рамках этой программы Виктора Ивановича должны были командировать в Бельгию на Международный симпозиум «Логические системы, их теория и применение» (15.09-20.09.1969). Там он собирался выступить с докладом «Использование булевых, лукасевичевых и бочваровых операций в теории логических систем». Однако поездка и выступление не состоялись. Примерно в 1965 г. В.И. Шестаков заключил договоры с Издательством физико-математической литературы на написание справочника «Методы функционального анализа и структурного синтеза релейных систем» и книги «Математическая логика в теории релейных схем», а с Учпедгизом - на подготовку учебного пособия «Математическая логика и автоматизация вычислений». Все эти книги, учитывая большие научные достижения и опыт Шестакова, могли оказаться полезными для расширения и углубления исследований по применению математической логики в технике и для ее преподавания. $\mathrm{K}$ сожалению, ни один из этих издательских проектов не был осуществлен. ${ }^{20}$

1970-е годы были наиболее богатыми по числу признаний научных достижений В.И. Шестакова и их уровню. В 1970 г. в энциклопедии «История отечественной математики» (Т. 4. Кн. 2. Киев. Изд-во «Наукова Думка». 1970) отмечалось: «Одно из первых применений математической логики в теории контактных схем (1934 г.) принадлежит В.И. Шестакову. Пользуясь аналоги- 
ей между операциями исчисления высказываний и контактными схемами, он разработал метод синтеза схем, не содержащих мостиковых соединений». И там же: «Еще в 1938 г. В.И. Шестаков (одновременно с американским ученым К. Шенноном) для решения задач синтеза релейно-контактных схем применил аппарат булевой алгебры». ${ }^{21}$ В 1973 г. В.М. Глушков в статье «Кибернетика» в 3-м издании БСЭ (БСЭ. Т. 12. 1973) указал, что «В 1938 г. К. Шеннон (США), а в 1941 г. В.И. Шестаков (CCCP) показали возможность использования для синтеза и анализа релейно-контактных схем аппарата математической логики. Тем самым было положено начало развитию современной теории автоматов». В 1975 году во 2-м издании «Логического словаря-справочника» Н.И. Кондакова было написано: «Математическое доказательство применимости алгебры Буля в теории и практике контактных и контактно-релейных схем было дано в 1938 г. русским ученым В.И. Шестаковым и американским инженером К.Э. Шенноном».

В конце 1970-х - 1980-е гг. В.И. Шестаков после долгого перерыва вернулся к логико-алгебраическим методам изучения линейных электрических цепей, с которых в 1935 году он начинал свою научную деятельность. В серии работ, опубликованных в журнале «Вестник Московского университета. Серия 3: физика, астрономия» (1976. № 2; 1977. № 2; 1979. №№ 4,6; 1982. № 1; 1983. № $2 ; 1984$. № 1) он распространил разработанные им ранее логико-алгебраические методы расчета двухполюсных электрических схем с последовательными и параллельными соединениями элементов на многополюсные схемы. Кроме того, в этот, последний период своей жизни Виктор Иванович нашел новые применения трехзначной логики - для установления эквивалентности электрических двухполюсников и для анализа размерностей физических величин (см. тот же журнал, 1983. № 4; 1987. № 3). Эти последние работы В.И. Шестакова отказывались публиковать ведущие журналы СССР, публиковавшие его прежде: «Доклады АН CССР», «Автоматика и телемеханика» и др. Более того, он встречал непонимание и у коллег по прежней работе в МГУ, так что даже в родном университетском журнале его статьи проходили не просто (см. ниже воспоминания акад. О.Б. Лупанова). Заметим, что и в эти последние годы 
жизни Виктор Иванович продолжал с интересом следить за работами других ученых по применениям математической логики, переводил их и реферировал, доведя число опубликованных рефератов до 76.

В 1967 г. В.И. Шестакову исполнилось 60 лет. Однако, достигнув пенсионного возраста, он не ушел на пенсию, а продолжал по-прежнему интенсивно трудиться на кафедре общей физики физфака МГУ еще почти 15 лет - до 1982 года. Более того, дважды - в 1971 и 1978 годах он был слушателем факультета повышения квалификации МГУ по специальности «общая физика». Выйдя в июне 1982 г. окончательно на пенсию, он фактически продолжал трудиться - сначала и.о. доцента, а с 1984 г. - и.о. ассистента, что было вызвано его недостаточной материальной обеспеченностью. $\mathrm{K}$ моменту выхода на пенсию состав семьи Шестакова сильно изменился. Еще в 1941 г. на фронте погиб его старший брат Владимир Иванович Шестаков. В 1962 году дочь Ирина Викторовна вышла замуж за Виктора Васильевича Самохвалова и в 1963 г. родила сына Евгения, сделав В.И. Шестакова дедом. В 1977 году умерла теща Виктора Ивановича Э.С. Гурфинкель. Изменились и жилищные условия: в 1971 г. Виктор Иванович купил однокомнатную кооперативную квартиру 16,7 кв.м. по ул. 26 Бакинских комиссаров и переехал в нее со своей семьей, оставив семье дочери двухкомнатную квартиру по ул. Лобачевского. В 1984 году скончалась Геня Абрамовна - жена Виктора Ивановича, и семидесятивосьмилетний ученый был вынужден снова переехать в семью дочери, оставив свою кооперативную квартиру внуку. Свою смерть вследствие рака пищевода Виктор Иванович Шестаков встретил 3 мая 1987 года. При этом он работал практически до последнего дня жизни: последняя из его неопубликованных рукописей помечена 3 апреля 1987 г., а две его последние опубликованные статьи вышли из печати в июне 1987 года, уже после смерти автора («Вестник Московского университета, Серия 3». 1987. № 3). Эти последние годы его жизни ознаменовались рядом новых признаний его научных заслуг. 16.06.1982 г. в отзыве «О научных трудах В.И. Шестакова», составленном в связи с его предстоявшим 75-летним юбилеем и окончательным уходом на пенсию и подписанном известными учеными-кибернетиками 
Б.В. Бирюковым, В.А. Горбатовым, В.Г. Лазаревым и Г.Н. Поваровым, указывалось, что юбиляр «установил возможность и показал плодотворность приложений математической логики в прикладной математике, вычислительной технике и кибернетике; разработал первые логические методы анализа и синтеза релейных схем; положил начало математическому проектированию дискретных технических устройств; разработал теорию многотактных релейных схем, оказавшую влияние на формирование более общей теории конечных автоматов; внес большой вклад в развитие молодого искусства программирования ЦВМ». 22 февраля 1983 года в газете «Московский университет» появилось еще одно, на этот раз необычное - анонимное признание В.И. Шестакова под названием «Чего не увидели другие», в котором утверждалась бесспорность его приоритета в разработке метода расчета релейно-контактных схем на основе математической логики. ${ }^{22}$

Каким человеком был В.И. Шестаков в жизни? Мнения на этот счет сильно расходятся. Проф. Д.А. Поспелов, опираясь на личные впечатления М.А. Гаврилова, пишет, что «интроверт по складу личности, Шестаков не любил шумных сборищ, накала научной полемики, столкновения интересов». ${ }^{23}$ Ему вторит преемник М.А. Гаврилова на посту зав. лабораторией автоматов ИПУ РАН А.А. Амбарцумян (записано автором 10.12.2004 г.): «Шестаков был очень скромный и тихий человек. Однажды он пришел к нам в институт на семинар и тихо стоял в сторонке. Его провели в зал, усадили. Он слушал, но не задавал никаких вопросов... На него не ссылались по очевидной причине: для математиков это была не математика, а для инженеров, составлявших большинство, - далекая от практики теория, не обеспечивающая процесс проектирования устройств». А вот что сообщила автору многолетняя коллега Виктора Ивановича по Физфаку МГУ Алевтина Прохоровна Крылова (записано автором 09.12.2004 г.): «Он был прекрасный человек, легкий, не способный сделать ничего плохого людям, скромный. Всю жизнь вел только практику. Лекции читать ему никогда не давали, хотя в довоенные годы степень кандидата наук, которую он имел, уже ценилась высоко. Публиковался он в молодые годы мало. В этом нет ничего необычного, тогда вообще мало публиковались - 
меньше, чем сейчас, особенно по логике - к ней было отношение какое-то не то. А его защита без публикаций - тогда все так защищались. Вообще, в его поведении не было ничего необычного, выделяющего его из массы. В послевоенные годы его стали публиковать легко в трудах МГУ. Но в других изданиях он проходил трудно». По воспоминаниям Е.В. Самохвалова - внука В.И., - он «несмотря на то, что был крупным ученым, был прост в обращении, в нем полностью отсутствовали какие-либо барьеры перед живым общением с рабочими, дворниками, сантехниками. Часто работники, приглашенные делать ремонт, после выполнения работы приглашались дедом за общий стол, и он с ними беседовал, как с равными. Совсем другое мнение у академика РАН О.Б. Лупанова, бывшего в 1980-е и последующие годы деканом Мехмата МГУ (записано автором 08.12.2004 г.): «Он был довольно странный человек, и эти странности есть в его поздних публикациях. Ко мне приходили из редакции «Вестника МГУ. Сер. Физика, астрономия», показывали статьи Шестакова, которые они не понимали, и спрашивали, какие рецензии писать, и вообще, что делать со статьями. Я отвечал, что рецензии надо писать снисходительно-одобрительные, без обсуждения по существу, хотя эти статьи действительно были очень странные». По нашему мнению, В.И. Шестаков не был ни скромным и тихим, ни обыкновенным, как все, ни странным - он был просто Ученым, различные стороны личности которого проявлялись в зависимости от обстоятельств и их связи с его наукой и интересами. Так, когда доклад на семинаре, где он присутствовал, был ему не интересен, то он был «тихим и скромным», а когда он приносил статью в «Вестник МГУ. Сер. Физика, астрономия» и пытался объяснить важность применения математической логики в физике, то для физиков он выглядел странным. Когда же ему приходилось бороться за опубликование своих научных работ, он был напорист и оперативен, привлекал в свою поддержку влиятельных в научном мире ученых, проявлял большую активность и в большинстве случаев добивался своего, демонстрируя отнюдь не «тихость и скромность».

У В.И. Шестакова, по воспоминаниям его внука Е.В. Самохвалова, были весьма независимые и свободолюбивые общественнополитические взгляды. Эти взгляды были характерны резким 
неприятием всякой несправедливости. Он весьма негативно относился к советскому строю и коммунизму, регулярно слушал зарубежные радиостанции и по ним ориентировался в состоянии дел в мире и стране. По словам дочери В.И. Самохваловой И.В., он был очень чувствительным человеком, сочувствовал больным, гонимым и т.д. Он часто подписывал письма в защиту ученых-диссидентов (например, А.С. Есенина-Вольпина). В.И. считал себя наполовину русским, наполовину поляком внуком участника польского восстания 1863 года и с гордостью повторял, что в его «жилах течет кровь борца за свободу польского народа». Однако при всем свободолюбии он не был чистым «отрицателем» и любил Россию.

\section{6 Заключение}

Подводя итоги, необходимо, прежде всего, отметить, что Виктор Иванович Шестаков был выдающимся ученым в области приложений математической логики и алгебры к моделированию, анализу и синтезу электрических схем, а также релейноконтактных и других дискретных устройств автоматики и вычислительной техники. ${ }^{23}$ Две пламенные страсти смолоду владели им: страсть к науке, которой он оставался предан всю жизнь, и страсть всегда и во всем быть первым. Его преданность науке принесла богатый урожай. Это, во-первых, открытие им в 1938 г. возможности применения аппарата алгебры логики для расчета, анализа и синтеза статики работы линейных электрических и релейно-контактных схем, во-вторых, открытие в 1953-54 гг. теории многотактных релейных схем, явившихся прообразом конечного автомата, и в-третьих, разработка (в составе коллектива) первой в CCCP системы программирования для цифровых вычислительных машин. Были у него и другие значительные научные достижения (например, содержательная логическая теория размерностей в физике). Что же касается его стремления быть всегда первым, то это ему обычно не удавалось. Так, честь открытия возможности использования алгебры логики для расчета релейно-контактных схем В.И. Шестаков разделил, по общему признанию, с американцем К.Э. Шенноном и японцами А. Накашима и М. Ханзава, понятие конечного автомата независимо от В.И. Шестако- 
ва и примерно в то же самое время ввели американцы А. Бёркс, Д. Райт, Д. Хаффмен, С. Клини, румын Г. Моисил, советские ученые Б.А. Трахтенброт и Н.Е. Кобринский, а еще до войны - М.А. Гаврилов (многотактные релейные схемы), а в разработке первых в Советском Союзе методов программирования вместе с В.И. Шестаковым участвовало еще 3 известных ученых: Л.А. Люстерник, М.Р. Шура-Бура и А.А. Абрамов, причем в период разработки аналогичные методы уже существовали на Западе. Эти и другие подобные им факты задевали В.И. Шестакова и побуждали иногда к действиям, которые по-человечески можно понять, но трудно оправдать. Нашему герою, по существу, не нужно было ничего, кроме реальных научных результатов и их достаточно широкого признания. $\mathrm{Pa-}$ ди них он пожертвовал многим, в частности, защитой докторской диссертации (для этого надо было оторвать несколько лет жизни и подлинной научной работы и «пробивать» возникающие перед ним трудности). Его научные заслуги отмечены во многих книгах, статьях, энциклопедиях и справочниках. Правда, начальство Виктора Ивановича отметило его заслуги более скромно: за почти полувековую деятельность в МГУ он удостоился лишь двух почетных грамот от месткома, праздничного адреса к 70-летию от коллектива своей кафедры да 2 приказов с благодарностью «за многолетнюю безупречную учебную, методическую и научную работу».

Пройдут годы. Многое встанет на свое место. Взаимоотношения В.И. Шестакова с его научными конкурентами и чиновниками от науки, его подчас необычные взгляды и поступки и другие, сугубо личные, обстоятельства потеряют общественный интерес. И тогда на первый план выступит то, что было главным в этом человеке - Ученый Божьей милостью. И признание придет само собой. А то, что оно пришло позже на 50 или 100 лет, не будет иметь никакого значения, ибо что такое 50-100 лет по сравнению с вечностью?

\section{7 Библиография основных работ В.И. Шестакова}

В приведенную ниже библиографию включены все известные автору публикации В.И. Шестакова на русском языке. Отсутствуют только переводы его работ на иностранные языки, вы- 
полненные им рефераты для реферативных журналов и несколько неопубликованных рукописей.

1. Шестаков В.И. Авторское свидетельство на изобретение № 35435: счетная машина типа Однера. М. 31.03.1934. С. 1-8.

2. Шестаков В.И. Некоторые математические методы конструирования и упрощения двухполюсных электрических схем класса А. Дисс. . канд. физ.-мат. наук. М.: НИИ физики МГУ. 1938. Часть I. С. 1-34; Часть II. С. 1-79.

3. Шестаков В.И. Алгебра двухполюсных схем, построенных исключительно из двухполюсников (алгебра А-схем) // Журнал технической физики. 1941. Т. 11. Вып. 6. С. 532-549 (март 1941 г.).

4. Шестаков В.И. Алгебра двухполюсных схем, построенных исключительно из двухполюсников (алгебра А-схем) // Автоматика и телемеханика. 1941. № 2. С. 15-24 (апрель 1941 г.) (сокращенный вариант статьи 3 ).

5. Шестаков В.И. Об одном символическом исчислении, применимом к теории релейно-контактных схем // Ученые записки Московского университета: Теория вероятностей. Вычислительная математика. Номография. М. 1944. Вып. 73. С. 45-48 (сильно сокращенный вариант статьи 3).

6. Шестаков В.И. Представление характеристический функций предложений посредством выражений, реализуемых релейноконтактными схемами // Известия АН СССР. Сер. математическая. 1946. Т. 10. № 6. С. 529-554.

7. Шестаков В.И., Абрамов А.А., Люстерник Л.А., ШураБура М.Р. Решение математических задач на автоматических цифровых машинах. Программирование для быстродействующих электронных счетных машин. М.: Изд-во АН СССР. 1952. $327 \mathrm{c}$.

8. Шестаков В.И. Моделирование операций исчисления предложений посредством простейших четырехполюсных схем // Вычислительная математика и вычислительная техника. Вып. 1. М.: Изд-во АН СССР. 1953. С. 56-89.

9. Шестаков В.И. Алгебраический метод анализа автономных систем двухпозиционных реле // Автоматика и телемеханика. 1954. № 2. C. 107-123. 
10. Шестаков В.И. Алгебраический метод синтеза автономных систем двухпозиционных реле // Автоматика и телемеханика. 1954. № 4. С. $310-324$.

11. Шестаков В.И. О преобразовании моноциклической последовательности в возвратную // Доклады АН СССР. 1954. Т. 98. № 4. C. 541-544.

12. Шестаков В.И. Алгебраический метод синтеза многотактных релейных систем // Доклады АН СССР. 1954. Т. 99. № 6. C. 987-990.

13. Синтез электронных вычислительных и управляющих схем // Пер. с англ., ред. В.И. Шестаков. М.: ИИЛ. 1954. 360 с.

14. Шестаков В.И. Векторно-алгебраический метод анализа и синтеза многотактных релейных систем // Труды 3-го Всесоюзного математического съезда. Т. 1. М.1956. С. 190-191.

15. Гаврилов М.А., Поваров Г.Н., Рогинский В.Н., Харкевич А.Д., Шестаков В.И. Математическая проблематика структурной теории релейных схем // Труды 3-го всесоюзного математического съезда. Т. 2. М. 1956. С. 150-151.

16. Шестаков В.И. Алгебраический метод синтеза многотактных схем $r$-позиционных реле // Доклады АН СССР. 1957. Т. 112. № 1. C. $62-65$.

17. Шестаков В.И. Перфокарточный метод синтеза многотактных релейных систем // Автоматика и телемеханика. 1958. № 6. C. $592-605$.

18, 19. Шестаков В.И. Математическая логика и автоматика // Математика в школе. 1958. № 6. С. 9-20; 1959. № 1. С. 19-39.

20. Шестаков В.И. Перфокарточный метод синтеза многотактных систем многопозиционных реле // Автоматика и телемеханика. 1959. № 11. С. 1496-1506.

21. Шестаков В.И. Моделирование операций исчисления высказываний посредством релейно-контактных схем // Логические исследования. Вып. 2. М.: Изд-во АН СССР. 1959. С. 315351.

22. Шестаков В.И. Об одной теории синтеза смешанных релейно-контактных схем класса П // Вестник Московского университета. Серия 3. Математика, механика, астрономия, физика, химия. 1959. № 6. С. 215-223.

23. Шестаков В.И. К вопросу о синтезе смешанных релейно- 
контактных схем класса П // Известия вузов СССР. Радиофизика. 1960. Т. 3. № 3. С. 526-533.

24. Шестаков В.И. О двойной арифметической интерпретации трехзначного исчисления высказываний, используемой при моделировании этого исчисления посредством релейно-коммутаторных схем // Применение логики в науке и технике. М.: Издво АН CCCP. 1960. С. 341-376.

25. Шестаков В.И. О теории синтеза смешанных релейно-контактных схем класса П // Вестник Московского университета. Серия 3. Физика, астрономия. 1961. Т. 2. № 4.

26. Шестаков В.И. Синтез однотактного сумматора двоичных чисел, построенного из двухпозиционных коммутаторов и поляризованных реле // Вопросы теории математических машин. T. 2. M. 1962. C. 232-239.

27. Шестаков В.И. О взаимоотношении некоторых трехзначных логических исчислений // Успехи математических наук. 1964. T. 19 (116). C. 177-181.

28. Бирюков Б.В., Калужнин Л.А., Шестаков В.И. Логические машины // Философская энциклопедия. Т. 3. М.: Советская Энциклопедия. 1964. С. 232-234.

29. Шестаков В.И. Алгебра коммутаторных схем (алгебра четырехполюсников, соединенных двухполюсными коммутаторами) // Синтез релейных схем. Труды Международного симпозиума по теории релейных устройств и конечных автоматов. ИФАК. М.: Наука. 1965. С. 87-96.

30. Шестаков В.И. О некоторых расширениях исчислений Бочвара и Клини до функционально полных трехзначных исчислений // Научно-техническая информация. Серия 2. Информационные процессы и системы. М. 1967. № 12. С. 12-17.

31. Шестаков В.И. Об одном фрагменте исчисления Бочвара // Информационные вопросы семиотики, лингвистики и автоматического перевода. Вып. 1. М.: ВИНИТИ. 1971. С. 102-115.

32. Шестаков В.И. О матричном представлении каскадных соединений четырехполюсников // Вестник Московского университета. Серия 3. Физика, астрономия. 1976. Т. 17. № 2. С. $168-$ 176.

33. Шестаков В.И. Об одном универсальном методе символического представления каскадных соединений двухпроводных 
цепей // Вестник Московского университета. Серия 3. Физика, астрономия. 1977. Т. 18. № 2. С. 11-19.

34. Шестаков В.И. Об одном методе символического представления каскадных и параллельных соединений нормальных $N$-проводных цепей // Вестник Московского университета. Серия 3. Физика, астрономия. 1979. Т. 20. № 4. С. 45-55.

35. Шестаков В.И. Операции обращения и инверсии комплексных физических величин // Вестник Московского университета. Серия 3. Физика, астрономия. 1979. Т. 20. № 6. С. 47-55.

36. Шестаков В.И. Метод символического представления параллельных и каскадных соединений $N$-полюсных цепей / / Вестник Московского университета. Серия 3. Физика, астрономия. 1982. T. 23. № 1. С. 31-38.

37. Шестаков В.И. Основные законы алгебры параллельных соединений $N$-полюсников // Вестник Московского университета. Серия 3. Физика, астрономия. 1983. Т. 24. №2. С. 59-66.

38. Шестаков В.И. О применении трехзначной логики для анализа отношений между физическими величинами $/ / \mathrm{Bec} /-\mathrm{T} /-$ ник Московского университета. Серия 3. Физика, астрономия. 1983. T. 24. № 4. C. 40-45.

39. Шестаков В.И. Основные законы алгебры двухполюсных соединений двухполюсников и кортежей этих соединений // Вестник Московского университета. Серия 3. Физика, астрономия. 1984. T. 25. № 1. С. 41-48.

40. Шестаков В.И. Об эквивалентности пассивных двухполюсников // Вестник Московского университета. Серия 3. Физика, астрономия. 1987. Т. 28. №3. С. 31-36.

41. Шестаков В.И. О применении трехзначной логики в теории размерностей физических величин // Вестник Московского университета. Серия 3. Физика, астрономия. 1987. Т. 28. № 3. C. $37-42$.

\section{8 Примечания}

${ }^{1}$ В.И. Шестаков в течение всей жизни стремился быть первым и в учебе, и в научной деятельности. Часто это ему удавалось (хотя и не всегда) Однако связанные с этим хлопоты нередко отвлекали его от собственно творческой научной работы. Приведенная в тексте цитата взята из книги [8], гл. 4. 
2 Авторское свидетельство № 35435 на изобретение счетной машины типа Однера для производства арифметических действий как с положительными, так и с отрицательными числами. Это изобретение никогда не фигурировало в публикациях В.И. Шестакова, и о нем, по-видимому, до настоящего времени не было известно научно-технической общественности.

${ }^{3}$ Интересно, что В.И. Шестаков никогда впоследствии не работал по специальности, указанной в его дипломе.

${ }^{4}$ Причина взаимонепонимания между аспирантом и его научным руководителем была, по-видимому, в том, что второй всю жизнь занимался исследованием непрерывных процессов, а первый хотел заниматься изучением дискретных процессов и вдобавок вел себя очень независимо.

${ }^{5}$ История появления и роль этой работы в жизни как самого В.И. Шестакова, так и всего научного сообщества сложна и запутана. Работа «Реле и релейные схемы», включающая главу «Алгебра релейных схем», судя по данным архива В.И. Шестакова, была выполнена в декабре 1934 г. - январе 1935 г. (возможно, это произошло под влиянием акад. Н.Н. Лузина, сотрудника МГУ, занимавшегося тогда логикой и явившегося впоследствии одним из инициаторов создания Ин-та автоматики и телемеханики АН СССР). Эта работа, судя по оформлению, не предназначалась для опубликования. Затем Виктор Иванович представил ее в дирекцию НИИ физики МГУ с просьбой считать его работу диссертацией, однако позже забрал ее. После этого в течение 14 лет работу никто не вспоминал. Сам Шестаков не сослался на нее даже в своей диссертации 1938 г., хотя такая ссылка была бы очень уместной, поскольку у него в этот момент не было ни одной публикации. Более того, его руководитель В.И. Гливенко и проф. С.А. Яновская в совместной обзорной статье «Логика математическая» 1938 г. (БСЭ. Т. 37. М. 1938) ни словом не упоминают о ней. И лишь в 1948 году та же С.А. Яновская в обзорной статье «Основания математики и математическая логика» («Математика в СССР за 30 лет. 19171947». Т. 2. М.-Л. 1948) написала: «Предположение о возможности построения алгебры релейно-контактных схем на базе алгебры логики впервые было высказано в 1910 г... Эренфестом... Это предположение было подтверждено в конце 1934 - нача- 
ле 1935 г. В.И. Шестаковым... Эти результаты были изложены в работе «Алгебра релейных схем», написанной В.И. Шестаковым в январе 1935 г. Работа не была опубликована, но легла в основу его кандидатской диссертации». После этого тезис о приоритете Шестакова в открытии в 1935 г. алгебры релейных схем был повторен рядом советских ученых (П.С. Новиков. Отзыв о работах В.И. Шестакова. 15.10.1949 - см. в тексте; М.А. Гаврилов. Теория релейно-контактных схем. М.-Л. 1950; В.Н. Рогинский. Построение релейных схем управления. М.-Л. 1964; История отечественной математики. Т. 4. Кн. 2. Киев. 1970. С. 443; В.А. Успенский. Очерки истории информатики в России. Новосибирск. 1998. С. 124; М.Г. Гаазе-Раппопорт. Там же. С. 232). Однако другие работу «Алгебра релейных схем» 1935 года даже не упоминают (О.П. Кузнецов. Релейно-контактных схем теория // Автоматизация производства и промышленная электроника. Т. 3. М. 1964; В.М. Глушков. Синтез цифровых автоматов. М. 1962; Н.Е. Кобринский и Б.А. Трахтенброт. Введение в теорию конечных автоматов. М. 1962; М.А. Айзерман, Л.А. Гусев, Л.И. Розоноэр, И.М. Смирнова, А.А. Таль. Логика. Автоматы. Алгоритмы. М. 1963; Э.А. Якубайтис. Асинхронные логические автоматы. Рига. 1966; В.М. Глушков. Кибернетика / БСЭ. Т. 12. 1973; Логика: биобиблиографический справочник (Россия-СССР-Россия). СПб. 2001). По нашему мнению, рукопись «Реле и релейные схемы» с главой «Алгебра релейных схем», составленная В.И. Шестаковым в период наивысшего обострения его отношений с научным руководителем по аспирантуре проф. Гореликом, имела своей ближайшей целью отчитаться за 1-й семестр аспирантуры, а следующей целью добиться смены темы диссертации и научного руководителя. Ее содержание должно было лишь показать серьезность новой заявляемой темы - не более того. Именно поэтому Шестаков подготовил ее очень быстро - в течение месяца, сразу отдал в дирекцию НИИ физики МГУ, а после достижения своей цели забрал ее. Тот факт, что ни он, ни его руководитель никогда не упоминали ее, можно считать свидетельством того, что они не считали ее законченной работой, содержащей определенные новые научные результаты. Однако около 1947 г. В.И. Шестаков, уже знакомый с исследованиями других ученых по его теме 
(см. прим. $6,10,18,24)$ и озабоченный вопросами своего приоритета, познакомил с работой С.А. Яновскую. Искра упала на благодатную почву (хорошо известна большая доброжелательность С.А. к молодым ученым) и в нужное время (это был пик борьбы против низкопоклонства перед Западом, за приоритет отечественной науки и техники). В итоге - вышеупомянутый обзор С.А. Яновской, с установлением приоритета Шестакова в построении логической алгебры релейно-контактных схем. А дальше высокий научный и человеческий авторитет С.А. привел к тиражированию данной установки в СССР. И это при том, что умозаключение С.А. Яновской о приоритете является по меньшей мере некорректным, поскольку она сравнивает неопубликованную рукопись Шестакова, которую никто не видел, с опубликованными работами его конкурентов. Необходимо также добавить, что анализ научной биографии С.А. Яновской показывает, что она не могла быть свидетелем создания работы В.И. Шестакова «Реле и релейные схемы» и ее главы «Алгебра релейных схем». Поэтому ее поддержка приоритета Шестакова, провозглашенная в 1948 году, очевидно, была основана только на рукописях и устных пояснениях самого Шестакова. Такое обоснование приоритета ученого явно недостаточно. Это подтверждают и воспоминания И.В. Самохваловой - дочери В.И. Шестакова, которая свидетельствует, что В.И. и С.А. после войны «связывали дружеские отношения... Они неоднократно обсуждали вместе интересующие их проблемы и историю с предвоенными работами Шестакова Яновская знала очень хорошо от него самого».

6 Интересно, что практически одновременно с В.И. Шестаковым и независимо от него были подготовлены и защищены еще две диссертации - K.Э. Шеннона (Shannon C.E. A Symbolic Analysis of Relay and Switching Circuits. Kembrige, USA. 1938) и A. Риттера (Ritter A. Beitrage zur Schaltlehre. Wien. 1938) и подготовлена диссертация О. Плехля, защищенная позже (Plechl O. Die Kombinatorik der Strompfade elektrotechnischer Schaltungen. Wien. 1943; свидетельство подготовки этой работы еще в 1938 г. cm. H. Piesch. Archiv fur Elektrotechnik. 1939. Bd. 33. № 10). Bce четыре диссертации решали одну и ту же задачу математического моделирования релейно-контактных схем с помощью булевой алгебры логики. 
7 Позицию В.И. Шестакова и его убежденность в плагиате, который якобы совершил В.А. Розенберг, мы считаем не оправданными по следующим причинам (см. также ${ }^{18}$ ): а) совпадение отдельных мест работ двух авторов не является доказательством плагиата, совершенного одним из них; так, в статье Шестакова в ЖТТФ. 1941. Т. 11. Вып. 6 формулы (4), (4'), (5), (5’), (7), (8o), (8o'), (15), (15') совпадают соответственно с формулами (1a), (1b), (2a), (2b), (8), (9b), (9a), (14a), (14b) статьи Шеннона в Trans. of the AIEE. 1938. T. 57 - ну и что? б) Розенберг, в отличие от Шестакова, рассматривает эквивалентные преобразования релейно-контактных схем не только с параллельными и последовательными, но и с мостиковыми соединениями; в) Розенберг приводит лишь часть известных законов булевой алгебры логики, не используя термин «булева» и правильные названия законов, что подтверждает его незнание алгебры логики и вообще низкий уровень математической подготовки; этого не было бы, если Розенберг был знаком с диссертацией Шестакова; г) у главного редактора журнала «Автоматика и телемеханика» не было никакого резона посылать диссертацию Шестакова в Ленинград на рецензию Розенбергу (именно в этом случае у последнего появлялась возможность плагиата), поскольку в это время в его непосредственном подчинении в Институте автоматики и телемеханики (Москва) работал гораздо более квалифицированный специалист М.А. Гаврилов, уже в то время к.т.н., автор 40 печатных работ, в т.ч. 3 монографий; д) в период предполагаемой присылки диссертации Розенбергу (март 1938 г.) в стране происходили массовые репрессии, тысячи людей расстреливали, хотя они не совершали никаких преступлений; для того чтобы в этих условиях совершить несомненное преступление в форме плагиата, а затем выставить его на всеобщее обозрение, опубликовав статью в наиболее читаемом журнале, надо было быть полным идиотом; Розенберг, занимавший в это время высокий пост (гл. инженер Ленпроектконторы «Сев. зап. эл. монтаж»), явно не был идиотом; е) два независимых эксперта, оценивавших обе работы - диссертацию В.И. Шестакова и статью В.А. Розенберга (Д.И. Марьяновский и эксперт, действовавший по заданию редактора журнала «Автоматика и телемеханика»), а также редактор журнала член-корр. АН СССР В.И. Ковален- 
ков - специалист в данной области, - факта плагиата не установили; ж) в «Дневнике» 22.04.1940 г. В.И. Шестаков жалуется: «Утром прочел в только что вышедшем № 1 за 1940 год журнале «Автоматика и телемеханика» статью В.А. Розенберга. Очень большое совпадение содержания с содержанием 2-й части моей диссертации. Еще большее совпадение с моей рукописью «Реле и релейные схемы». Что ж, теоретически «большое совпадение содержания» статьи Розенберга с содержанием диссертации Шестакова было возможно, хотя вероятность такого совпадения близка к нулю (см. выше пп. а)-е)). Однако «еще большее совпадение» статьи с рукописью «Реле и релейные схемы» невозможно даже теоретически, так как В.И. Шестаков свои рукописи никому не давал; з) М.А. Гаврилов в период описываемых событий уже входил в редколлегию «Автоматики и телемеханики» и, будучи хорошо знакомым с работами В.И. Шестакова, без труда обнаружил бы плагиат в статье Розенберга, если бы он там был, еще на стадии ее подготовки к печати. Это, при хорошо известной порядочности Гаврилова, неизбежно привело бы к отклонению статьи. Однако этого не произошло. Более того, впоследствии Гаврилов ссылался на статью Розенберга как на заслуживающее внимания самостоятельное исследование (см., например: Гаврилов М.А. Теория релейно-контактных схем. М.--Л. 1950). Заметим еще, что объективно В.А. Розенберг своей публикацией помог В.И. Шестакову, подтолкнув его к опубликованию собственных результатов.

8 У редакции журнала «Автоматика и телемеханика» была веская причина отказаться от публикации переписки с В.И. Шестаковым и В.А. Розенбергом (кроме причины, связанной с сомнениями в наличии плагиата в статье Розенберга): появление переписки на страницах журнала могло привести к обвинениям против него в попытке опорочить советских ученых, со всеми вытекающими отсюда последствиями. Очень возможно, что редактор журнала сначала запросил мнение «компетентных органов» и лишь после этого принял «нужное решение», сообщив о нем Шестакову. Несмотря на отказ В.И. Шестакову в публикации его письма с обвинениями против Розенберга, редакция «Автоматики и телемеханики» отнеслась к Виктору Ивановичу доброжелательно. Об этом свидетельствует появление в жур- 
нале его статьи «Алгебра двухполюсных схем...» всего через 5 месяцев после представления требуемой формы рукописи. Большую роль в этом, видимо, сыграл член редколлегии журнала М.А. Гаврилов.

9 Отказ В.И. Шестакова от всяких попыток решить вопрос о своем приоритете в суде вызван отчасти тем, что по характеру он был интроверт и потому старался избегать открытого столкновения интересов и публичной полемики. Другой причиной, по нашему мнению, было то, что к концу эпопеи он, видимо, осознал, что у него нет юридических доказательств, необходимых для судебного иска.

10 Две работы Пиш были напечатаны в журнале Archiv fur Elektrotechnik. 1939. №№ 10,11 и уже в начале 1940 г. были доступны читателям наших столичных библиотек. На эти работы В.И. Шестаков ссылался уже в первой своей статье (ЖТФ. 1941. Т. 11. Вып. 6). В свою очередь, в первой работе Х. Пиш приводились сведения о публикациях А. Накашимы и М. Ханзавы и неопубликованной работе О. Плехля.

${ }^{11}$ Со статьей K. Шеннона в Trans. AIEE. 1938 (июнь). Vol. 57 В.И. Шестаков мог легко познакомиться уже осенью 1938 года в библиотеке своего родного МГУ, которая выписывала этот журнал. Далее, статья К.Э. Шеннона в журнале Trans. AIEE. 1938 (июнь). Vol. 57 была прореферирована в № 2 «Автоматики и телемеханики» 1941 г. - том самом, в котором появилась сокращенная версия статьи В.И. Шестакова «Алгебра двухполюсных схем...». Однако о Шенноновской статье Шестаков мог узнать и раньше, за несколько месяцев до выхода в свет этого журнала от М.А. Гаврилова, который курировал в журнале тематику релейных схем и с которым он контактировал. Интересно отметить, что В.И. Шестаков никогда не ссылался на работы других известных ему ученых, занимавшихся применением логических методов в технике (за исключением одной, явно вызванной требованием рецензента, ссылки на работы Х. Пиш $\left.{ }^{10}\right)$. Это поведение было, по-видимому, своеобразной формой его самоутверждения в качестве первооткрывателя этих методов.

12 Первые работы по применению аппарата алгебры логики для изучения релейно-контактных и других дискретных схем, выполнявшиеся в СССР и Европе в 1930-е - начале 1940-х го- 
дов, использовались преимущественно при построении различных управляющих систем (управление железнодорожным транспортом, управление электрическими системами и т.д.), в отличие от аналогичных работ в США, которые сразу ориентировались на использование дискретных схем при построении цифровых вычислительных машин, и работ японских ученых, связанных с применениями теории дискретных схем в телефонии.

13 Эти и последующие отзывы в СССР на работы В.И. Шестакова, безусловно, готовились при его непосредственном участии, в соответствии со сложившейся в стране традицией. Конечно, трудно представить себе подобную технологию появления отзывов на научные работы, скажем, американцев Н. Винера и К. Шеннона или англичанина Р. Эшби. Однако, оценивая действия Шестакова, следует иметь в виду, что он всегда хотел быть первым, ${ }^{1}$ а за подтверждение его первенства в виде некоторого отзыва на его работы при сложившихся в нашей стране традициях он неизбежно должен был делать шаги, не допустимые с точки зрения западного ученого и вообще научной этики.

14 Командирование В.И. Шестакова в докторантуру было совершенно естественно и несомненно согласовано с ним. Тем большее изумление вызывают отчеты Виктора Ивановича о пребывании в докторантуре. В предварительном отчете В.И. сообщает о выполнении теоретической части диссертации и невыполнении практической (применение к ЦВМ) из-за неясности вопроса о секретности. Но никто не мешал В.И. выяснить вопрос о секретности (он много раз проделывал это, оформляя акты об отсутствии в его статьях секретных сведений) и в случае наличия такой секретности исключить соответствующий материал из диссертации либо оставить его и защищать закрытую диссертацию. В окончательном отчете он жалуется совсем на другое на бытовые проблемы и трудности с публикацией результатов. Где же правда? А правда, по нашему мнению, была совсем в другом: на горьком опыте подготовки и защиты кандидатской диссертации В.И. Шестаков убедился в том, что эта процедура чревата задержкой в подготовке публикаций и риском утери приоритета. Поэтому он, по-видимому, принял решение вместо защиты диссертации опубликовать в кратчайшие сроки свои новые результаты. И сразу «забыл» о бытовых и иных проблемах. 
По свидетельству Е.В. Самохвалова, внука В.И., было еще одно обстоятельство: жена Шестакова Г.А. Гурфинкель в 1952 году как «безродный космополит» была уволена из военной академии, где она преподавала философию. После этого Шестакова ясно предупредили, что докторской степени ему не видать!

15 Подозрения В.И. Шестакова в адрес М.А. Гаврилова были, на наш взгляд, необоснованны. М.А. Гаврилов был первым, кто еще в 1938 г. правильно оценил не только теоретическое, но и прикладное значение работ В.И. Шестакова для проектирования дискретных систем управления. После этого В.И. приобрел в лице М.А. соратника, способного вложить в борьбу за новые идеи огромные силы. По единодушному мнению многочисленных учеников, М.А. Гаврилов был «предан науке и честен перед собой и своими учениками» (Д.А. Поспелов. Школа МАГа // Новости искусственного интеллекта. 1997. № 3). И еще - даже «противники его научных взглядов никогда не превращались для него в личных врагов» (там же). По свидетельству А.А. Амбарцумяна - участника гавриловского коллектива, М.А. Гаврилов пытался привлечь В.И. Шестакова, которого он высоко ценил, к работам своего коллектива. Однако это ему не удалось, поскольку В.И. не любил работать в коллективе. Несмотря на это, Гаврилов всегда помнил о Шестакове и посильно помогал ему: включал в престижные коллективные публикации, давал необходимые отзывы и т.д. В частности, многочисленные публикации В.И. Шестакова в журнале «Автоматика и телемеханика» появились во многом благодаря поддержке М.А. Гаврилова. При этом все они выходили в свет в сроки, обычные для этого журнала, а некоторые ${ }^{8}-$ досрочно.

16 Это столкновение засвидетельствовано академиком О.Б. Лупановым (записано автором 08.12.2004 г.). А.Н. Колмогоров был, безусловно, прав в том, что процессы в многотактных релейных схемах, изучавшиеся В.И. Шестаковым, представляют собой весьма частный, вырожденный случай цепей Маркова, теория которых была построена еще в начале XX в. Однако он был не прав в другом: частные случаи могут иметь важные и полезные свойства, которых нет в общем случае, так что переход к изучению частного случая может привести к научному открытию. Вряд ли ученый такого уровня, как А.Н. Колмогоров, не 
понимал этого. Однако ему - одному из создателей теории марковских процессов, видимо, было трудно согласиться с тем, что в недрах созданной им теории рождается новая наука (впоследствии она получит название теории автоматов), а он к этому не причастен. Аналогично в период с 1948 по 1959 год он не мог примириться с тем, что на базе его собственных работ, а также работ А.Я. Хинчина и Н. Винера по анализу и прогнозированию случайных процессов именно Винер создал новую науку - кибернетику. Именно отсюда проистекает критика Колмогоровым кибернетики в 1950-е гг.

17 См.: Кольман Э. Мы не должны были так жить. N.-Y. Chalidze. 1982.

18 Анализ Г.Н. Поварова содержит наибольшее, по сравнению с другими работами 1940-90-х гг., число участников открытия логических методов моделирования дискретных систем. Тем не менее, в нем упущены некоторые из участников: Р. Эдлер, О. Плехль, А. Риттер и др. (см. ${ }^{6}$ и $\left.[2,3,6-9]\right)$. Заметим еще, что, приводя в числе участников открытия фамилию В.А. Розенберга, Г.Н. Поваров тем самым отвергает обвинения в плагиате, выдвинутые против этого ученого В.И. Шестаковым.

19 Приоритет В.И. Шестакова в применении символической логики к анализу и синтезу релейных схем может быть установлен путем сопоставления дат официального представления общественности законченных работ всех участников исследований в этой области (дат представления диссертаций, дат их защиты, дат опубликования работ и т.д.) и сравнительного анализа содержания этих работ. Но приведенный в письме отзыв В.И. Гливенко оценивает исследования Шестакова только за сентябрьдекабрь 1935 г., не считая их законченными, что видно из текста отзыва: «Шестаков работает над разработкой найденного им математического аппарата для аналитического выражения электрических схем с последовательными и параллельными соединениями. Этот аппарат дает возможность автоматически решать задачу о получении простейших статических схем для некоторых классов релейных схем. Шестаков разработал до конца математический аппарат для аналитического выражения схем двухполюсников в предельном случае бесконечно малых и бесконечно больших сопротивлений, получил ряд результатов для схем 
двухполюсников в непредельном случае конечных сопротивлений, нашел математическую формулировку задачи об упрощении схем двухполюсников. Исследовательская работа Шестакова позволяет рассчитывать на успешное доведение ее до конца». (Напомним, что впереди у В.И. Шестакова было еще целых два года пребывания в аспирантуре!). Кроме того, эти незаконченные исследования В.И. Шестакова не были официально представлены общественности. Таким образом, доказать приоритет В.И. Шестакова так, как это делает в своем письме декан физфака МГУ, нельзя. Кстати сказать, тот же декан в 1938 г. писал: «Отзыв Гливенко точно фиксирует идейную сторону исследований Шестакова, которые по своему содержанию и предложенным методам решения практических задач перекликаются с многими работами советских и зарубежных ученых. В связи с задержкой публикаций исследований В.И. Шестакова (они не сразу были встречены радушно) роль Виктора Ивановича в применении алгебры логики Дж. Буля недостаточно четко отмечается в советской и зарубежной печати». Отсюда видно, что раньше декан придерживался других взглядов на проблему приоритета, считая работу Шестакова одной из многих работ в данной области. Более полный анализ затронутых здесь проблем дан в статье В.И. Левина «История открытия логического моделирования статики технических устройств» [6]. Заметим еще, что автор письма - декан Физфака МГУ, не являясь специалистом в логике и не имея ни одной публикации в этой области (его специальность - физическая теория горения!), делает в своем письме исторический экскурс алгебраических построений в логике, восходящих к Лейбницу, Дж. Булю, Кутюра, Эренфесту. Это заставляет думать, что подлинным автором текста письма декана физфака МГУ, опубликованного в «Вестнике МГУ». Серия 3. 1968. № 5, был, вероятно, сам В.И. Шестаков. ${ }^{13}$.

20 Причина, по которой В.И. Шестаков отказался от выполнения договоров на издание всех трех книг, по нашему мнению, была та же, по которой за 12 лет до этого он отказался от защиты докторской диссертации, ${ }^{14}$ а именно, нежелание тратить время на работу, непосредственно не связанную с творчеством, получением новых научных результатов, их опубликованием и защитой своего приоритета. 
21 Две приведенные даты - 1934-й и 1938-й годы не согласуются между собой. На самом деле первым официально зафиксированным публичным представлением результатов В.И. Шестакова по применению алгебры логики для синтеза релейноконтактных схем была его защита кандидатской диссертации 28.09.1938 года на физическом факультете МГУ. Первая же публикация этих результатов состоялась лишь в 1941 году.

22 Этот документ вызывает много вопросов: 1) Кто был автором анонимного хвалебного отзыва? 2) Почему этот автор был заинтересован в признании приоритета работ В.И. Шестакова? 3) Чем мотивировалось его желание скрыть свое имя? И т.д. Очевидно, что никто из врагов В.И. Шестакова либо просто безразличных к нему людей не мог быть автором хвалебного отзыва - им мог быть только кто-то из его друзей или из начальства, заинтересованный в признании работ друга или коллеги. Однако никому из этих людей не было никакого смысла скрывать свое имя: ведь хвалить - не ругать. K тому же начальники анонимок обычно не пишут, не желая рисковать карьерой. Выходит, что никто из знавших В.И. Шестакова не мог написать этот отзыв. Но в таком случае можно предположить, что автором текста отзыва был сам Виктор Иванович! В пользу этого говорят следующие доводы. Во-первых, он был единственным человеком, который был заинтересован в признании приоритета работ В.И. Шестакова и при этом желал скрыть свое имя. Во-вторых, название отзыва подсказано книгой: Вебер Ю.Г. Когда приходит ответ. М.: Детская литература. 1977 (в книге есть фраза «...он сумел подсмотреть то, чего не увидели до сих пор те, кто годами варился в этой области...»). Чтобы дать такое название, автор отзыва должен был хорошо знать содержание указанной книги и то, что под именем одного из главных героев Василия Игнатьевича Шестопалова выведен Виктор Иванович Шестаков. Конечно, лучше всех это знал сам В.И. Шестаков. Кстати, в его архиве хранится экземпляр книги Ю.Г. Вебера. В-третьих, если бы подлинным автором отзыва был кто-то из знакомых В.И. Шестакова, он бы непременно показал ему текст, чтобы избежать ошибок. Между тем, отзыв содержит, по меньшей мере, одну ошибку: дата публикации основного конкурента Шестакова в споре за приоритет - Шеннона указана неверно 
(сдвинута на более позднее время). Так что наше предположение, что автором текста анонимного отзыва на работы В.И. Шестакова был он сам, вполне обосновано. Остается объяснить, зачем Виктор Иванович в своей публикации сознательно допустил указанную ошибку. Ответ очевиден: только в этом случае, обратившись впоследствии в редакцию с письмом, содержащим исправление указанной ошибки, он отводил от себя возможные обвинения в авторстве документа, не совместимого с нормами научной этики. И действительно, машинописная копия такого письма от 13.03.1983 г. хранится в архиве В.И. Шестакова ([5], с. 29). В этом письме В.И. содержится исправление указанной ошибки и еще одной аналогичной ошибки в отношении другого его конкурента Накашимы. Однако последней ошибки в публикации газеты «Московский университет» от 22.02.1983 г. нет: там Накашима вообще не упоминается. Это означает, что свое письмо в газету Шестаков написал еще до публикации в ней анонимного отзыва на его работы, используя другой, первоначальный вариант отзыва, в котором содержались обе упомянутые выше хронологические ошибки. Отсюда следует, что В.И. Шестаков был автором (или соавтором) опубликованного в газете отзыва.

23 Поспелов Д.А. Школа МАГа // Новости искусственного интеллекта. - 1997. - № 3.

${ }^{24}$ М.А. Гаврилов, считавший работу В.И. Шестакова революционной, в то же время полагал, что ее значение не было понято даже автором (Амбарцумян А.А. Михаил Александрович Гаврилов (к 100-летию со дня рождения) // Проблемы управления. 2003. № 4). Эта оценка представляется несправедливой. В.И. Шестаков и другие ученые, работавшие в 1930-е гг. К.Э. Шеннон, А. Накашима, М. Ханзава, А. Риттер, О. Плехль, Х. Пиш, В.А. Розенберг и др. отлично понимали значение их работ, впервые позволивших заменить эквивалентные преобразования (а, значит, и проектирование) релейно-контактных схем чисто математической (а, значит, и полностью формализованной) задачей эквивалентного преобразования булевой логической функции, определяющей проводимость схемы. Конечно же, эти ученые не занимались прикладными, техническим вопросами, связанными с поиском наилучших алгоритмов преобразо- 
вания, учетом размерности схем и т.д. Однако принципиальную проблему возможности формализации проектирования релейноконтактных схем с помощью алгебры логики разрешили именно они. Следующему поколению ученых (М.А. Гаврилов, Г.Н. Поваров, В.Н. Рогинский, В.Г. Лазарев, Д.А. Поспелов и др.) уже не нужно было решать эту проблему, и они взялись сразу за решение указанных прикладных вопросов.

\section{Литература}

[1] Волгин Л.И. Шестаков - основоположник континуального этапа развития математической логики // Современная логика: проблемы теории, истории и применения в науке. Материалы VI Всероссийской научной конференции. СПб.: Изд-во СПбГУ, 2000.

[2] Левин В.И. Из истории открытия логического моделирования технических устройств (статика) // Прикладная философия и социология. Труды Международной конференции «Континуальные алгебраические логики, исчисления и нейроинформатика в науке и технике». Т. 1. Ульяновск: Изд-во УлГТУ, 2004.

[3] Левин В.И. История открытия логического моделирования технических устройств // Вестник Тамбовского университета. Серия: Естественные и технические науки. 2004. Т. 9. № 4.

[4] Бажанов B.A. Шестаков и Шеннон: разные судьбы творцов одной красивой идеи // Вопросы истории естествознания и техники. 2005. № 2 .

[5] Бирюков Б.В., Верстин И.С., Левин В.И. Жизненный и научный путь В.И. Шестакова - создателя логической теории релейно-контактных схем // Логические исследования. Вып. 14. М.: Наука, 2007.

[6] Левин В.И. История открытия логического моделирования статики технических устройств // Вопросы истории естествознания и техники. 2007. № 1 .

[7] Бирюков Б.В., Борисова О.А., Левин В.И. О вкладе В.И. Шестакова в создание логической теории релейных схем // Вопросы философии. 2009. № 3.

[8] В.И. Шестаков и открытие логического моделирования в технике / Под ред. В.И. Левина. Пенза: Изд-во Пензенской государственной технологической академии, 2009

[9] Левин В.И. История открытия логического моделирования устройств и систем // VII Международная научно-практическая конференция «Проблемы образования в современной России и на постсоветском пространстве». Сборник статей. Пенза: Изд-во Приволжского дома знаний, 2006. 